\title{
8
}

\section{Corporate governance and firm performance}

Mei Wen

Industrial competition and ownership diversification have contributed significantly to China's industrial growth since economic reforms began (Wen 2002a). ${ }^{1}$ Although no large-scale transformation of ownership took place in the state industrial sector before 1995 and growth occurred mainly outside the state-planned sector (Naughton 1994), the development of non-state owned industrial firms and market-based competition have raised the prominence of China's industry in the world economy. The majority of state-owned enterprises (SOEs) made either apparent or genuine losses in the 1990s, and, according to the third national industrial census, held in 1995, many manufacturing industries had excess production capacity. Further fundamental reforms to SOEs are required to remove remaining inefficiencies. The industrial policy guideline 'keep the large and let the small go' for the reform of SOEs was a major policy response to the situation and commenced in 1995.

Since the 1980s, SOE reform has involved forms of contracting, leasing, merger and even bankruptcy, but large-scale transformation of ownership structures did not begin until 1996. The newly legislated township and village-owned enterprises (TVE) law provided private TVEs with the same legal protection as collective TVEs. Since 1996, gaizhi has become a popular term to describe the SOE reforms. Gaizhi, directly interpreted as 'transforming system', implies the reform of stateowned enterprises towards economic entities that compete in a market system. The market-supporting institutions and market mechanisms that developed after the systematic introduction of markets since 1992 has laid a stronger base for the transformation of SOEs' ownership structures. The establishment of two 
stockmarkets in Shanghai and Shenzhen enabled SOEs to transform their ownership structure by gradually reducing the state-owned shares through listing and trading. SOE inefficiencies have forced the government to introduce more fundamental reforms in the sector, even though the social security system is still insufficient to assist the large numbers of workers who have been and will be laidoff during the reform process.

In most cases, gaizhi of SOEs implies a degree of ownership transformation, in many cases experimental or gradual. While the majority of firms that undertook gaizhi sought to transform their ownership structure, a small group of firms in the IFC survey (Garnaut et al. 2005) tried instead to improve performance by mimicking private-sector corporate governance and financial practices. According to Garnaut et al. (2005), around 80 per cent of SOEs had transformed ownership in some way by the end of 2001, with partial or total transfer of ownership to private entities occurring in approximately 70 per cent of the gaizhicases.

Ownership structure has implications for efficiency due to incomplete information, transaction costs and different operational objectives. Because of incomplete information, imperfect contracts and vaguely defined property rights, agency costs are usually much higher in SOEs than in privately-owned firms. In transitional economies, the soft budget constraints faced by SOEs (Li and Liang 1998, Qian and Roland 1996) provide larger scope for increasing agency costs. Some studies on transitional economies regard privatisation as a necessary condition for firms to tighten budgets (Kornai 1986, Kornai et al. 2003, Earle and Estrin 2003). Distribution of the rights to claim residual income and to control the firm has strong implications for efficiency. Improvement in enterprise internal efficiency must be based on the efforts of managers to reduce production costs. However the separation of the rights of control from the rights to claim residual income indicates that owners and managers have conflicting objectives. Due to information asymmetries, the behaviour of managers cannot be fully observed. To improve internal efficiency, owners can design incentive contracts to induce managers to reduce production costs, align management objectives with the interests of owners or strengthen the monitoring of management behaviour. ${ }^{2}$ In SOEs, chief managers retain residual control rights. They are the risk takers. The nominal owners of SOEs and final bearers of the consequences of risky behaviour, however, are the 1.3 billion Chinese people. Due to the great number of nominal owners, there is little incentive for managers to protect owners' interests. Monitoring by government officials has little effect when personal gains from rent seeking are not caught and punished, and the negative phenomena are reinforced when banks are also state-owned and directed by rent-seeking managers and government officials 
(Che 2002; Lin 2005; Zhu 1998)—ownership transformation becomes essential to improve the performance of SOEs.

Different methods of transforming the ownership structure lead to different ex post ownership and governance structures. As the 'keep the large and let the small go' policy guideline indicates, the majority of firms to be privatised were SOEs within industries that did not have strongly increasing returns to scale. The ex post ownership and governance structure and market conditions are the major determinants of post-privatisation performance.

\section{Different methods of gaizhi}

When the SETC and IFC conducted a survey of SOE gaizhi in 11 Chinese cities in 2002, they identified ten broad types of gaizhi
1) listing through public offering
2) internal restructuring without ownership transfer
3) bankruptcy before restructuring
4) change into companies with shares through internal privatisation
5) sale
6) leasing, contracting or takeover
7) leasing with internal share division
8) combination of sale and leasing
9) transforming into joint venture by inviting foreign investment
10) other types.

Among these ten categories, internal restructuring without ownership transfer, privatisation through internal distribution of shares, sale and leasing includes subtypes according to changes in management form, restructuring, new financing approaches for internal restructuring without ownership transfer, the registered enterprise forms after gaizhi for change into companies with shares through internal privatisation, different buyers for sale, and the different agents for leasing, contracting or takeover.

Owing to concerns over the sample size, four gaizhi types were chosen to study relative effectiveness. The first type is category one gaizhi reforms, where firms undertook stocklisting and incorporation.

The second type occurred when firms underwent internal restructuring without transferring ownership. This type of gaizhi reform mimics the governance approach of corporations by setting up boards of directors and company rules and regulations. Although companies remain owned by the state, the gaizhi reforms allow firms to function more as independent legal entities and reduce state intervention. 
The third type of gaizhi reform was internal privatisation of firms, after which firms registered as limited liability companies. Under the fourth type of gaizhi reform, the enterprise privatised internally but registered as cooperative or collectives. Both types are the subcategories of change into companies with shares through internal privatisation.

Company Law requires that the maximum number of shareholders in a limited liability company to be 50 . The major ex post difference between firms that undertook the third and fourth type of gaizhi reforms is that the maximum number of internal shareholders after the third type of reform is 50 , while the number of shareholders after the fourth type of reform exceeds 50 . In other words, ownership concentration in the former would be much higher than in the latter, which resemble collectives, and employees have a say in enterprise decision-making.

From an economic point of view, comparisons between type 1 and 2 reforms reveal differences in corporate governance between firms that privatise through public listing and firms that mimic trading counterparts while transforming without changing ownership. Comparison between type 1 and types 3 or 4 illustrates the difference between privatisation through public listing and internal privatisation. Differences in ownership concentration after type 3 and type 4 reforms can cause differences in performance.

\section{Sample methodology}

The sample used is from a survey of gaizhi firms in 11 Chinese cities-Harbin, Fushun, Tangshan, Lanzhou, Weifang, Xining, Zhenjiang, Huangshi, Chengdu, Hengyang, and Guiyang — conducted by the China Economy and Business Program of The Australian National University for IFC. The survey was administered by the State Economic and Trade Commission (SETC) of the State Council and its counterparts in the sample cities. The 11 city economic and trade commissions (ETCs) sent out 1,100 questionnaires to firms and registered a high return rate, with 683 questionnaires collected, predominantly from manufacturing firms (81 per cent). ${ }^{3}$ Among the responses, 375 firms provided details about the one or more forms of gaizhi reform they had pursued between 1986 and 2003. The survey questionnaire, however, only asked about the firm's accounting and financial situation between 1995 and 2001; gaizhi reforms undertaken before 1995 or after 2001 were excluded. This left 239 firms available for comparison. This study compares the change in performance from observations between 1995 and 2001, so firms that undertook reforms in only 1995 or only in 2001 must be excluded, leaving 222 firms that experienced different forms of gaizhi reforms from 1996 to 2000. Among these, the 
four types of gaizhi reforms incorporate a fraction of firms from the total sample. A sample of 109 firms that experienced form 1, form 2, form 3 or form 4 gaizhi reforms from 1996 to 2000 was examined. ${ }^{4}$

\section{Pre-gaizhi performance}

The 109 firms' pre-gaizhi performance in terms of average labour productivity, profit-asset ratio and the ratio of sum of profits and taxes to assets was compared. Labour productivity is calculated by dividing the firm's value-added by the number of employees on duty. The profit-asset ratio is the ratio of total profits after tax to total assets. The ratio of the sum of total profits and total taxes to total assets is denoted as the (profit+tax)-asset ratio. Many firms did not report at least one of these accounting variables so individual sample size is included in the three average pre-gaizhi performance tables (Tables 8.1-8.3). ${ }^{5}$

Type 1 firms had the highest average pre-gaizhi labour productivity and profitasset ratio, as well as the second highest average pre-gaizhi (profit+tax)-asset ratio. On average, only firms that undertook type 1 gaizhi reforms were making a profit prior to reform, the other firms were making losses (Table 8.2).

These two observations indicate that better-performing SOEs were chosen to be included in the type 1 gaizhi reform. Firms that undertook type 4 reforms had the highest average pre-gaizhi (profit+tax)-asset ratio, although on average they were making losses. Their contribution in taxes may have guaranteed government

\section{Table $8.1 \quad$ Average pre-gaizhi labour productivity}

\begin{tabular}{|c|c|c|c|c|}
\hline $\begin{array}{l}\text { Form of ownership transformation } \\
\text { Labour productivity }\end{array}$ & Form 1 & Form 2 & Form 3 & Form 4 \\
\hline (10,000 yuan/per employee) & 3.814035 & 1.251437 & 1.675711 & 1.578685 \\
\hline Number of observations & 8 & 22 & 11 & 11 \\
\hline
\end{tabular}

\section{Table 8.2 Average pre-gaizhi profit-asset ratio}

\begin{tabular}{lllll}
\hline Form of ownership transformation & Form 1 & Form 2 & Form 3 & Form 4 \\
Profit-asset ratio & 0.008952 & -0.022782 & -0.057536 & -0.027654 \\
Number of observations & 8 & 23 & 19 & 11 \\
\hline
\end{tabular}

\section{Table 8.3 Average pre-gaizhi(profit+tax)-asset ratio}

\begin{tabular}{lllll}
\hline Form of ownership transformation & Form 1 & Form 2 & Form 3 & Form 4 \\
(Profit+tax)-asset ratio & 0.037976 & 0.028533 & -0.033776 & 0.043079 \\
Number of observations & 8 & 20 & 19 & 11
\end{tabular}

Source: Based on data from Garnaut et al., 2005. China's Ownership Transformation: process, outcomes and prospects, the World Bank and International Finance Corporation, Washington, DC. 
support for financing and reduced the risk of being closed down. This may be a major reason why more than 50 people in the firm owned shares in the firm and firms registered as cooperatives rather than limited liability companies after undertaking privatisation. Although firms that undertook type 2 reforms were also making losses, the contribution of taxes was significant with an average profitasset ratio of -0.0228 , but average (profit+tax)-asset ratio of 0.0285 . This may be one reason why these firms did not experience ownership transformation. They also had a large number of employees. These firms have undertaken internal restructuring that emphasised enterprise governance.

The average performance of firms that undertook type 3 reforms was the worst in terms of the pre-gaizhi reform profit-asset and (profits+taxes)-asset ratios. This may be due to genuinely poor economic performance or accounting manipulation for low share prices during internal privatisation. The average labour productivity of these firms, however, was the second highest, so there may be scope to improve their profit-asset and (profits+taxes)-asset ratios. A smaller number of employees probably played some role in the choice of reform strategy in these organisations.

\section{Post-gaizhi performance}

First, on average, gaizhi forms 1 and 3 improved firms' profit-asset and (profit+tax)asset ratios, with type 3 reforms delivering the more significant improvements. While gaizhi forms 1 and 3 improved firms' performance on average, the difference could be partly due to the ex post differences in the match between control rights and rights to claim residual income, and partly due to differences in the scope for improvement.

Second, average labour productivity increased following all forms of gaizhi, especially strongly among firms that undertook type 1 reforms. Gaizhi reforms undertaken after 1995 resulted in firms laying off large numbers of workers. In 1997, the Ministry of Labour projected 4.3 million employees being laid off annually from SOEs over the following three years. Most firms did not have the optimal number of workers prior to reform, but type 1 firms gained far more autonomy over employment decisions in the transformation process, which likely explains their exceptional performance in labour productivity.

Third, on average, the profit-asset ratio and the (profit+tax)-asset ratio of firms that undertook type 2 or 4 gaizhi reforms decreased (Tables 8.4-8.6).

\section{Determinants of changes in enterprise performance}

To further confirm the effects of different forms of gaizhi reforms on firm performance, gaizhi form and year dummies are used in a regression analysis to explain the changes labour productivity. Observations about the percentage of 


\section{Table 8.4 Average change in labour productivity}

\begin{tabular}{|c|c|c|c|c|}
\hline $\begin{array}{l}\text { Form of ownership transformation } \\
\text { Change in labour productivity }\end{array}$ & Form 1 & Form 2 & Form 3 & Form 4 \\
\hline$(10,000$ yuan/per employee) & 2.1194 & 0.3759 & 0.4315 & 0.9487 \\
\hline Number of observations & 9 & 20 & 10 & 8 \\
\hline
\end{tabular}

\section{Table 8.5 Average change in profit-asset ratio}

\begin{tabular}{lllll}
\hline Form of ownership transformation & Form 1 & Form 2 & Form 3 & Form 4 \\
Change in profit-asset ratio & 0.00358 & -0.00877 & 0.05393 & -0.06978 \\
Number of observations & 8 & 21 & 13 & 9 \\
\hline
\end{tabular}

\section{Table 8.6 Average change in (profit+tax)-asset ratio}

\begin{tabular}{lllll}
\hline Form of ownership transformation & Form 1 & Form 2 & Form 3 & Form 4 \\
Change in (profit+tax)-asset ratio & 0.01827 & -0.01452 & 0.07075 & -0.06843 \\
Number of observations & 8 & 21 & 13 & 9
\end{tabular}

Source: Based on data from Garnaut et al., 2005. China's Ownership Transformation: process, outcomes and prospects, the World Bank and International Finance Corporation, Washington, DC.

company shares owned by the CEO were added to these variables to examine the determinants of the profit-asset and (profit+tax)-asset ratios (Table 8.7).

Form 1 gaizhi is significantly more effective at raising labour productivity than other types of gaizhi reform. Firms that undertook gaizhi in 1996 had smaller changes in labour productivity than those who undertook gaizhi in 1999. Form 1 gaizhi was less effective at raising labour productivity in 1997 while form 2 gaizhi reforms were less effective in 1999.

The percentage of shares owned by the CEO has a positive effect on the change in the firm's profit-asset and (profit+tax)-asset ratios, significant at the 0.01 and 0.10 level respectively. Form 2 gaizhi reforms significantly decrease the firm's profit-asset ratio, except during 1999. Similarly, form 4 gaizhi reforms have a significant negative effect on the firm's profit-asset ratio. In addition, form 3 gaizhi increases the firm's (profit+tax)-asset ratio at the 0.10 significance level, with the effect less significant in 2000. Form 4 gaizhi reforms decrease the firm's (profit+tax)-asset ratio.

Internal privatisation towards a limited liability company or form 3 gaizhi reforms significantly increased firms' profitability, although the average pre-gaizhi reform profitability of these firms was the lowest. The improvement can be attributed to more clearly-defined property rights, better governance structures and stronger incentives for CEOs that own shares in post-reform firms. 


\section{Table 8.7 Determinants of change in enterprise performance}

\begin{tabular}{|c|c|c|c|}
\hline Dform1 & $\begin{array}{l}\text { Labour productivity } \\
6.734^{* * *} \\
(5.256)\end{array}$ & Profit-asset ratio & $\begin{array}{l}\text { (Profit }+ \text { tax)- } \\
\text { asset ratio }\end{array}$ \\
\hline Dform2 & & $\begin{array}{l}-0.0885 \\
(-2.6603)\end{array}$ & \\
\hline Dform3 & & & $\begin{array}{c}0.0486^{*} \\
(1.8518)\end{array}$ \\
\hline Dform4 & & $\begin{array}{l}-0.0962 \\
(-3.7682)\end{array}$ & $\begin{array}{l}-0.0635^{\circ} \\
(-1.7974)\end{array}$ \\
\hline D1996 & $\begin{array}{l}-11.154^{* * *} \\
(-5.649)\end{array}$ & & \\
\hline D1998 & & $\begin{array}{l}0.0794 * * \\
(3.5932)\end{array}$ & $\begin{array}{c}0.033 \\
(1.2171)\end{array}$ \\
\hline D1999 & $\begin{array}{l}3.845^{*} \\
(3.465)\end{array}$ & & \\
\hline D2000 & & & \\
\hline $\begin{array}{l}\text { Percentage of } \\
\text { shares held by CEO }\end{array}$ & & $\begin{array}{l}0.0024 * * \\
(4.0033)\end{array}$ & $\begin{array}{c}0.0019^{*} \\
(2.0343)\end{array}$ \\
\hline Dform2*d1999 & $\begin{array}{l}-3.519^{* *} \\
(-2.569)\end{array}$ & $\begin{array}{l}0.0871^{* *} \\
(2.1564)\end{array}$ & \\
\hline Dform1*d1997 & $\begin{array}{l}-6.150^{\circ} \\
(-3.467)\end{array}$ & & \\
\hline Dform3*d2000 & & & $\begin{array}{l}-0.0414^{*} \\
(-0.9322)\end{array}$ \\
\hline Number of observations & 43 & 30 & 30 \\
\hline R-squared & 0.60 & 0.49 & 0.35 \\
\hline Adjusted R-squared & 0.56 & 0.41 & 0.25 \\
\hline
\end{tabular}

Notes: (1) The number in brackets is the t-statistic. (2) ${ }^{*},{ }^{\prime *}$ and ${ }^{* * *}$ indicate significance higher than 0.100 .05 and 0.01 levels, respectively.

Source: Based on data from Garnaut et al., 2005. China's Ownership Transformation: process, outcomes and prospects, the World Bank and International Finance Corporation, Washington, DC. 
While superficially similar to fully privatised firms, firms that undertook partial privatisation or became cooperatives experienced a decline in profitability. The positive effects of CEO shareholdings slightly counteracted this overall decline. The overall negative effects arose from high agency costs in the collective ownership structures, from higher coordination costs incurred through employee decision-making and the loss of former advantages from government support. These firms' average pre-reform (profit+tax)-asset ratio was the highest among the four types of firms.

Partial privatisation of SOEs through listing and trading in financial markets, form 1 gaizhi, improved profitability by facilitating the adoption of high-powered contracts and CEO share purchases. A significant increase in labour productivity among these firms was observed. It is ineffective for SOEs to mimic modern corporations, however, because the limited scope for improving the alignment between control and the right to claim residual income generates few incentives to improve performances. Governance changes provide the CEOs with greater control rights than prior to reforms, but increasing management's control without simultaneously increasing its ownership provides larger scope for managers to squander the SOE's assets. In fact, these firms experienced a decline in profitability after undertaking type 2 gaizhi reforms.

The effectiveness of enterprise governance is closely related to the ownership structure, especially when industrial competition is fierce. Further effieciency gain from strengthening market competition will be small in the short-run gain. Emphasising governance without accompanying changes to the ownership structure will not be effective (Table 8.7). In addition, the appropriate form of privatisation and choice of privatisation mechanism are more important for increasing efficiency (Wen 2002b, 2004). Some forms of privatisation may actually decrease firms' profitability. Without appropriate ex post governance, privatisation will fail to improve efficiency (Table 8.7).

\section{Conclusion}

Unlike papers that compared either the labour productivity, total factor productivity or technical efficiency between firms with different ownership types (Jefferson and Singh 1999, Wen et al. 2002, Zhang et al. 2001), this paper has compared the change in performance by firms that have undertaken different types of gaizhi reforms. The type of reform undertaken directly affects the labour productivity and profitability of the firm. 
However, this study is limited by a small sample size and lack of some desirable variables. Further investigation of industry-specific factors that examine the effects of different approaches of privatisation on internal efficiency and market performance are needed. A recent study by Bai et al. (2004) constructed a governance index to test the effect on the performance of stockmarket listed firms, which offers a useful tool for further studies on the effects of privatisation on firm performance.

\section{Notes}

1 According to State Statistical Bureau (various years), pure-industrial SOEs and enterprises with state-holding controlling shares dropped from around 118,000 units in 1995 to 34,280 units comprising either pure state ownership or state-held shares in 2003. The latter includes enterprises where the state does not hold controlling shares, which indicates that the influence of the state in the industrial sector has decreased more than the figure suggests. The share of pure-industrial SOEs and enterprises with state-holding controlling shares of the value of total industrial output in 1995 was 0.34 , while the 34,280 units with either pure-state ownership or state-holding shares in 2003 had a share of 0.37 of the value of total industrial output.

2 China's SOE reform before 1995 was by and large along the lines of using various contracts to provide management with stronger work incentives.

3 See Garnaut et al. (2005) for more details.

4 One firm that undertook two of the four types of gaizhi reforms from 1996 to 2000 is excluded.

5 Construction of the pre-gaizhi and post-gaizhi variables is as follows: if there is only one year before or after the gaizhi reforms, then the value of the calculated variable in that particular year is used. When two or even three years of data is available before or after gaizhi reforms, then the two year or three year average value of the calculated variable is used.

\section{References}

Bai, C., Liu, Q., Lu, J., Song, F. M. and Zhang, J., 2004. 'Corporate governance and market valuation in China', Journal of Comparative Economics, 32:599616.

Che, J., 2002 .'Rent seeking and government ownership of firms: an application to China's township-village enterprises', Journal of Comparative Economics, 30(4):787-811.

Earle, J.S. and Estrin, S., 2003. 'Privatisation, competition, and budget constraints: discipline enterprises in Russia' Economics of Planning, 36:1-22.

Garnaut, R., Song, L., Tenev, S. and Yao, Y., 2005. China's Ownership 
Transformation: process, outcomes and prospects, the World Bank and International Finance Corporation, Washington, DC.

Jefferson, G.H. and Singh, I., 1999. Enterprise Reform in China: Ownership, Transition and Performance, Oxford University Press, Oxford.

Kornai, J., 1986. 'The soft budget constraint', Kyklos, 39(1):3-30.

Kornai, J., Maskin., E. and Roland, G., 2003 .'Understanding the soft budget constraint', Journal of Economic Literature, 41(4):1095-136.

Li, D. and Liang, M., 1998. 'Causes of soft budget constraint: evidence on three explanations', Journal of Comparative Economics, 26(1):104-116.

Lin, S., 2005. 'Excessive government fee collection in China', Contemporary Economic Policy, 23(1): 91-106.

Naughton, B., 1994. Growing Out of Plan: Chinese economic reform, 1978-93, Cambridge University Press, New York.

Qian, Y. and Roland, G., 1996. 'The soft budget constraint in China', Japan and the World Economy, 8(2):207-23.

State Statistics Bureau, China Statistical Yearbook, China Statistical Publishing House, Beijing.

Wen, M.,2002a 'Competition, ownership diversification and industrial growth of China', in China 2002, (eds) by R. Garnaut and L. Song, Canberra: Asian Pacific Press: $63-80$.

— 2002b. 'Privatisation: theory and evidence' in Guoqiang Tian (ed.), Frontier Development of Modern Economics and Finance, Shangwu Press, Beijing:564609.

—, Li, D. and Lloyd, P., 2002 'O'Ownership and technical efficiency-a crosssection study on the third industrial census of China', Economic Development and Cultural Changes, 50(3):709-34.

- 2004. 'Bankruptcy, sale, and mergers as a route to the reform of Chinese SOEs', China Economic Review, 15(3):249-67.

Zhang, A., Zhang, Y. and Zhao, R., 2001. 'Impact of ownership and competition on the productivity of Chinese enterprises', Journal of Comparative Economics, 29:327-46.

Zhu, T., 1998. 'A theory of contract and ownership choice in public enterprises under reformed socialism: the case of China's TVEs', China Economic Review, 9(1):57-71. 